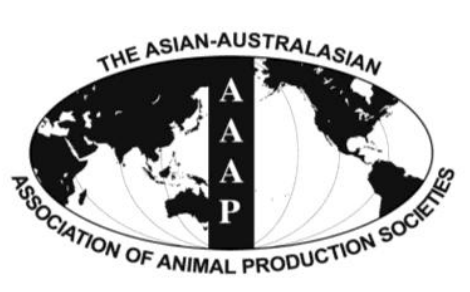

Open Access

Asian Australas. J. Anim. Sci.

Vol. 27, No. 2 : 201-208 February 2014

http://dx.doi.org/10.5713/ajas.2013.13448

www.ajas.info

pISSN 1011-2367 elSSN 1976-5517

\title{
Ensiling Characteristics and the In situ Nutrient Degradability of a By-product Feed-based Silage
}

\author{
Y. I. Kim ${ }^{\text {a }}$, Y. K. Oh ${ }^{1, a}$, K. K. Park ${ }^{2}$, and W. S. Kwak* \\ RIBS, Division of Food Bioscience, College of Health and Medical Life Sciences, Konkuk University, \\ Chungju, Chung-Buk 380-701, Korea
}

\begin{abstract}
This study was conducted to evaluate the ensiling characteristics and the in situ degradability of a by-product feed (BF)based silage. Before ensilation, the BF-based mixture was composed of 50\% spent mushroom substrate, $21 \%$ recycled poultry bedding, $15 \%$ ryegrass straw, $10.8 \%$ rice bran, $2 \%$ molasses, $0.6 \%$ bentonite, and $0.6 \%$ microbial inoculant on a wet basis and ensiled for up to 4 weeks. The BF-based silage contained on average $39.3 \%$ moisture, $13.4 \%$ crude protein (CP), and $52.2 \%$ neutral detergent fiber (NDF), $49 \%$ total digestible nutrient, and $37.8 \%$ physically effective $\mathrm{NDF}_{1.18}$ on a dry matter (DM) basis. Ensiling the BF-based silage for up to 4 weeks affected $(\mathrm{p}<0.01)$ the chemical composition to a small extent, increased $(\mathrm{p}<0.05)$ the lactic acid and $\mathrm{NH}_{3}-\mathrm{N}$ content, and decreased $(\mathrm{p}<0.05)$ both the total bacterial and lactic acid bacterial counts from $10^{9}$ to $10^{8} \mathrm{cfu} / \mathrm{g}$ when compared to that before ensiling. These parameters indicated that the silage was fermented and stored well during the 4-week ensiling period. Compared with rice or ryegrass straws, the BF-based silage had a higher $(\mathrm{p}<0.05)$ water-soluble and filterable fraction, a lower insoluble degradable DM and CP fraction ( $\mathrm{p}<0.05)$, a lower digestible NDF $(\mathrm{p}<0.05)$ fraction, a higher $(\mathrm{p}<0.05)$ DM and CP disappearance and degradability rate, and a lower $(\mathrm{p}<0.05)$ NDF disappearance and degradability rate. These results indicated that cheap, good-quality BF-based roughage could be produced by ensiling SMS, RPB, rice bran, and a minimal amount of straw. (Key Words: Spent Mushroom Substrate, By-product Feed, Silage, Degradability, Ruminant)
\end{abstract}

\section{INTRODUCTION}

The recent increase in the feed cost has exerted considerable pressure on the beef cattle industry. Many Asian countries including Korea import expensive sources of roughage from other nations. Providing good quality roughage to beef cattle is a general practice adopted to produce well-marbled beef. Accordingly, there is a need to develop a cheap, high quality by-product-based roughage source to relieve the problem of roughage scarcity faced by certain countries.

\footnotetext{
* Corresponding Author: W. S. Kwak. Tel: +82-43-840-3521, Fax: +82-43-851-8675, E-mail: wsk@kku.ac.kr

${ }^{1}$ National Institute of Animal Science, RDA, Suwon, Gyeonggido, Korea.

${ }^{2}$ Animal Resource Research Center, Konkuk University, Seoul, Korea.

${ }^{a}$ Y. I. Kim and Y. K. Oh contributed equally to this work.

Submitted Jul. 25, 2013; Accepted Sept. 22, 2013; Revised Oct. 24, 2013
}

Among the by-product feeds (BF) in Korea, cheap spent mushroom substrates (SMS) are produced on a large scale and are available nationwide in any season. The primary fiber sources in mushroom substrates include sawdust, cotton waste, corncobs, or straw. Previous research (Bae et al., 2006) from our laboratory revealed that sawdust-based SMS contained too much moisture (over 60\%) and neutral detergent fiber (NDF, 78.2\%), with a too low crude protein (CP, 7.2\%) and energy content. Therefore, to improve the nutritive quality of sawdust-based SMS, it should be mixed with other complementary feed sources. Furthermore, the storage of SMS is problematic, as this putrefies quickly due to its high moisture content (Kwak et al., 2008).

In comparison to SMS, recycled poultry bedding (RPB) is easily available and is a cheap proteinaceous feed (CP $22 \%$ ) with a low fiber content (NDF 53\%) (Kwak et al., 2008). When RPB was used to supplement sawdust-based SMS and ensiled, it improved the quality of SMS (with respect to storage and nutritive value) by increasing the $\mathrm{CP}$

Copyright (? 2014 by Asian-Australasian Journal of Animal Sciences This is an open-access article distributed under the terms of the Creative Commons Attribution Non-Commercial License (http://creativecommons.org/licenses/by-nc/3.0/) which permits unrestricted non-commercial use, distribution, and reproduction in any medium, provided the original work is properly cited. 
content while decreasing the fiber and lignin levels (Kwak et al., 2008). Moreover, processed RPB has been successfully used as a cattle feed (McCaskey et al., 1994; Fontenot, 2001).

Rice bran is produced on a large scale in most Asian countries. It is a cheap energy source containing a large total digestible nutrient (TDN) $(77.7 \%)$ fraction and a moderate level of ether extract (EE) (17.2\%) (NIAS, 2012).

Microbial inoculation is efficient in improving the ensiling characteristics of straw (Gao et al., 2008). A previous study conducted in our lab found that molasses and microbial inoculants could improve the fermentability and silage quality of SMS (Kwak et al., 2009). Since SMS contains low levels of readily fermentable carbohydrates, it was better to enrich it with molasses to stimulate the growth of lactic acid bacteria (LAB) and yeast (Weinberg et al., 2008). The inclusion of bentonite in a cattle diet formulation is an environmentally friendly practice as it considerably reduces manure gases. This practice also resulted in an increase in the mean body weight of Hanwoo steers by enhancing mineral availability (Lee et al., 2010b) and improved the meat quality of beef cattle (Cho et al., 2001; Kang et al., 2002). A minimal amount of straw containing large particles was used to provide the fiber required for normal ruminant activity. Conventionally, the anaerobic ensiling of high moisture-containing, by-productbased feedstuffs is effective in improving storage characteristics and resulted in enhanced nutrient conservation (Schneider et al., 1995; Fontenot, 2001; Weinberg et al., 2008).

Based on these factors, we devised a method for the development and manufacture of a cheap, high quality BFbased roughage by ensiling SMS with rice bran, RPB, straws, molasses, bentonite, and microbes. This study was conducted to evaluate the ensiling and storage characteristics and to determine in situ nutrient fractionation, disappearance rate, and degradability of the BF-based silage.

\section{MATERIALS AND METHODS}

\section{Manufacture of BF-based silage}

The SMS was collected fresh from a local oyster mushroom (Pleurotus osteratus) farm. The original mushroom substrate consisted of $47 \%$ sawdust, $18 \%$ kapok meal, $18 \%$ beet pulp, $13 \%$ corncobs, and $4 \%$ cottonseed meal. The SMS $(50 \%)$ was mixed with RPB (21\%), cut ryegrass straw $(15 \%)$, rice bran $(10.8 \%)$, molasses $(2 \%)$, bentonite $(0.6 \%)$, and microbial additives $(0.6 \%)$, and ensiled for up to 4 weeks. The microbial inoculants used in this experiment were isolated and identified previously in our lab (Kim et al., 2007b; Kim et al., 2008a) and include Enterobacter ludwigii KU201-3, Bacillus cereus KU206-3, Bacillus subtilis KU3, Saccharomyces cerevisiae, and Lactobacillus plantarum. The mixture was inoculated with the strains (each added at $0.12 \%$ [v/w]). Bacillus sp. and Enterobacter sp. were cultured in plate count broth (casein $5 \mathrm{~g}$, yeast extract $2.5 \mathrm{~g}$, and dextrose $1 \mathrm{~g} / \mathrm{L}$ ) at $36^{\circ} \mathrm{C}$ for $24 \mathrm{~h}$, Saccharomyces sp. in yeast male broth (0711, Difco Laboratories Inc., Detroit, MI, USA) at $30^{\circ} \mathrm{C}$ for $48 \mathrm{~h}$, and Lactobacillus sp. in MRS broth (0881, Difco Laboratories Inc., Detroit, MI, USA) at $36^{\circ} \mathrm{C}$ for $24 \mathrm{~h}$. As presented in Table 1, the SMS and ryegrass straw were used as a fiber source; the RPB, a protein source; and the rice bran and molasses, an energy source. The factors considered in feed formulation were moisture $(40 \pm 5 \%)$, CP (over 12\%), physically effective NDF (peNDF; over $25 \%$ ), and cost.

About 1.2-kg lots of the BF-based mixture sealed in two folds of poly-vinyl bags were prepared (with 10 replicates per treatment) and ensiled for a period of $0,3,5,7,14$, or $28 \mathrm{~d}$ at room temperature $\left(25^{\circ} \mathrm{C}\right)$. Samples were collected at each of the different ensiling periods and were stored at $-20^{\circ} \mathrm{C}$ for later analysis.

\section{In situ dacron bag test}

All animal care protocols were approved by the Konkuk

Table 1. The chemical composition of feed ingredients ${ }^{1}$

\begin{tabular}{|c|c|c|c|c|c|c|}
\hline Item & $\mathrm{SMS}^{2}$ & Ryegrass straw & $\mathrm{RPB}^{3}$ & Rice bran & Molasses & Bentonite \\
\hline & - & 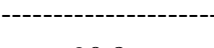 & $01-$ & - & 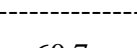 & \\
\hline Dry matter & 27.7 & 90.8 & 81.5 & 89.7 & 60.7 & 91.0 \\
\hline Crude protein ${ }^{4}$ & 12.2 & 5.4 & 22.8 & 15.2 & 3.9 & 0.2 \\
\hline $\mathrm{TP} / \mathrm{CP}$ & 82.3 & 67.0 & 53.9 & 75.0 & 9.5 & 24.3 \\
\hline NPN-CP/CP & 17.7 & 33.0 & 46.1 & 25.0 & 90.5 & 75.7 \\
\hline Ether extract & 0.5 & 0.5 & 0.6 & 19.7 & 0.7 & 0 \\
\hline Crude ash & 5.3 & 3.5 & 27.4 & 10.8 & 10.1 & 96.6 \\
\hline Neutral detergent fiber & 70.4 & 80.3 & 34.4 & 36.4 & 1.9 & 0 \\
\hline Acid detergent fiber & 62.0 & 65.2 & 29.4 & 18.4 & 0.6 & 0 \\
\hline Hemicellulose & 8.4 & 15.1 & 5.0 & 18.0 & 1.3 & 0 \\
\hline Acid detergent lignin & 33.5 & 22.6 & 13.4 & 5.1 & 0.2 & 0 \\
\hline Non-fibrous carbohydrate & 11.6 & 10.2 & 16.9 & 18.3 & 84.3 & 0 \\
\hline
\end{tabular}

${ }^{1}$ On a dry matter basis. ${ }^{2}$ Spent mushroom substrates (SMS). ${ }^{3}$ Recycled poultry bedding. ${ }^{4} \mathrm{TP}=$ True protein, NPN $=$ Non-protein nitrogen. 
University Institutional Animal Care and Use Committee. Two Holstein cows (having an average body weight of 626 $\mathrm{kg}$ ) fitted with ruminal cannula were used for the evaluation of in situ ruminal fractionation, disappearance rate, and degradability of BP-based silage by examining the dry matter (DM), NDF, and CP levels and comparing it to that of two most widely used, conventional, poor-quality roughage sources such as rice straw and ryegrass straw. Two trials were performed and four observations were made per treatment. The test animals were fed $4 \mathrm{~kg}$ of a formulated concentrate mix, $1 \mathrm{~kg}$ of rice straw, $1 \mathrm{~kg}$ of ryegrass straw, and $3 \mathrm{~kg}$ of BF-based silage on a daily basis to meet the nutritional requirements for their maintenance (NRC, 2001). The animals had free access to water. The BF-based silage used in this bag test was sampled from mixtures ensiled for $14 \mathrm{~d}$.

The in situ bag test was carried out according to the method by Ørskov et al. (1980). Samples were ground using a Wiley mill (Thomas Scientific, Model 4, NJ, USA). Particles in a size range of $63 \mu \mathrm{m}$ to $2 \mathrm{~mm}$ that were filtered using an experimental sieve were used for this test. The specimen (approximately $10 \mathrm{~g}$ ) was weighed and placed in a dacron bag (R1020, Ankom Technology, NY, USA) (bag size, $10 \times 25 \mathrm{~cm}$; mean pore size, $45 \mu \mathrm{m})$. The proportion of the wet sample weight to the dacron bag surface area was $20 \mathrm{mg} / \mathrm{cm}^{2}$, which satisfies the optimal proportion recommended by Nocek (1985).

Two hours after feeding, the bags containing test samples were incubated in the ruminal ventral sac for 0,24 , 48 , or $72 \mathrm{~h}$. After the incubation was completed, bags were retrieved, washed in cold, running water for $24 \mathrm{~h}$ until clear water emerged from the bag, and were dried at $60^{\circ} \mathrm{C}$ in a drying oven for $48 \mathrm{~h}$. The DM was classified into watersoluble and $45-\mu \mathrm{m}$ filterable, insoluble degradable, and non-degradable fractions (Armentano et al., 1986). It is assumed that the digestible NDF would be completely degraded in the rumen within $72 \mathrm{~h}$ (Smith et al., 1971). The portion of NDF that remained after $72 \mathrm{~h}$ of incubation was considered the indigestible fraction. The $\mathrm{CP}$ was classified into water-soluble and $45-\mu \mathrm{m}$ filterable, insoluble degradable, and non-degradable fractions. The portion of $\mathrm{CP}$ that remained after $48 \mathrm{~h}$ of incubation was considered the non-degradable fraction. Excluding the non-degradable fraction, residues at each incubation time were converted into a percentage, transformed into the natural logarithmic form, and subjected to a linear regression (Armentano et al., 1986). The degradation rate of degradable fraction was derived from the slope of the regression line. Computed degradation rates were calculated using Equation 1 to predict the ruminal degradability of DM, NDF, and CP fractions in the tested feeds (Orskov et al., 1983), and the assumed passage rates $\left(K_{\mathrm{p}} \mathrm{B}\right)$ were 0.025 and $0.05 / \mathrm{h}$ (Miller, 1982).

\section{Degradability $=\mathrm{A}+\left(K_{\mathrm{d}} \mathrm{B} \times \mathrm{B}\right) /\left(K_{\mathrm{d}} \mathrm{B}+K_{\mathrm{p}} \mathrm{B}\right) \quad$ Equation 1}

Where $\mathrm{A}=$ the soluble and filterable fraction, $\mathrm{B}=$ the insoluble degradable fraction, $K_{\mathrm{d}} \mathrm{B}=$ the degradation rate of degradable fraction, and $K_{\mathrm{p}} \mathrm{B}=$ the passage rate of degradable fraction.

The ruminal disappearance rates of $\mathrm{DM}, \mathrm{NDF}$, and $\mathrm{CP}$ were calculated for all incubation times $(0,24,48$, or $72 \mathrm{~h})$.

\section{Chemical analysis}

Immediately before analysis, all samples were dried and ground to pass through a 1-mm filter using a sample mill (Cemotec, Tecator, Sweden). The dry matter fraction was quantified by drying the samples at $60^{\circ} \mathrm{C}$ for $48 \mathrm{~h}$ to reach a constant weight. The $\mathrm{CP}, \mathrm{EE}$, and crude ash content were determined by the AOAC method (2000). The NDF and acid detergent fiber (ADF) content were analyzed using the method described by Van Soest et al. (1991). The nonfibrous carbohydrate (NFC) content was calculated as 100$(\mathrm{NDF} \%+\mathrm{CP} \%+\mathrm{EE} \%+\mathrm{ash} \%)$. The true protein (TP) content was measured by evaluating the nitrogen fractions precipitated in a 5\% trichloroacetic acid solution. The nonprotein nitrogen (NPN)-CP fraction was calculated as CP minus TP. The indigestible protein (ADF-CP) content was determined by the method described by Goering and Van Soest (1970).

The $\mathrm{pH}$ was measured using a $\mathrm{pH}$ meter (HI9321, Hanna Instrument, Portugal). The water-soluble carbohydrate (WSC), lactic acid, and $\mathrm{NH}_{3}-\mathrm{N}$ contents were determined by the Dubois (1956) method, the Barker and Summerson (1941) method, and the Chaney and Marbach (1962) method using a UV spectrometer (S-1100, Scinco, Korea), respectively. The amount of volatile fatty acids such as acetic and butyric acids was assessed by the method described by Erwin et al. (1961) using gas chromatography (Thermo Electron Corporation, OH, USA).

Microbial analyses of the samples (sample size, $25 \mathrm{~g}$ ) were conducted according to the AOAC (2000) method as follows: total bacterial count was determined on plate count agar (PCA, Difco Laboratories Inc., Detroit, MI, USA) incubated at $30^{\circ} \mathrm{C}$ for $48 \mathrm{~h}$. LAB were determined on MRS agar plate (Difco Laboratories Inc., Detroit, MI, USA) incubated at $36^{\circ} \mathrm{C}$ for $24 \mathrm{~h}$.

\section{Statistical analysis}

All statistical analyses were conducted using one-way analysis of variance, using the general linear model procedure (Statistix7, 2000). Tukey's multiple range test was used to compare the treatment means. Linear and quadratic trends for the samples ensiled for the different time periods were tested using polynomial contrasts. The data derived from the in situ bag test were processed using a randomized complete block design (Statistix7, 2000). The 
Table 2. Changes in chemical composition (DM basis) of the by-product feed-based silage following different lengths of ensilation ${ }^{1}$

\begin{tabular}{|c|c|c|c|c|c|c|c|c|c|}
\hline \multirow[t]{2}{*}{ Item $^{2}$} & \multicolumn{6}{|c|}{ Ensilation period } & \multirow[t]{2}{*}{ SE } & \multicolumn{2}{|c|}{$\begin{array}{c}\text { Polynomial } \\
\text { contrast degree }\end{array}$} \\
\hline & $0 \mathrm{~d}$ & $3 d$ & $5 \mathrm{~d}$ & $7 \mathrm{~d}$ & $14 \mathrm{~d}$ & $28 \mathrm{~d}$ & & Linear & Quadratic \\
\hline & ---- & & . & $70-----$ & $-1--$ & --------- & & & \\
\hline Dry matter & $62.2^{\mathrm{a}}$ & $60.6^{\mathrm{b}}$ & $59.8^{\mathrm{b}}$ & $60.8^{\mathrm{b}}$ & $60.3^{\mathrm{b}}$ & $60.7^{\mathrm{b}}$ & 0.45 & 0.264 & 0.038 \\
\hline Organic matter & $88.3^{\mathrm{a}}$ & $87.3^{\mathrm{b}}$ & $87.7^{\mathrm{ab}}$ & $87.3^{\mathrm{b}}$ & $87.8^{\mathrm{ab}}$ & $87.6^{\mathrm{ab}}$ & 0.28 & 0.680 & 0.577 \\
\hline Crude protein $(\mathrm{CP})$ & $12.6^{\mathrm{b}}$ & $13.6^{\mathrm{a}}$ & $13.4^{\mathrm{a}}$ & $13.4^{\mathrm{a}}$ & $13.2^{\mathrm{a}}$ & $13.2^{\mathrm{a}}$ & 0.19 & 0.754 & 0.137 \\
\hline $\mathrm{TP} / \mathrm{CP}$ & $65.1^{\mathrm{a}}$ & $60.7^{\mathrm{ab}}$ & $60.8^{\mathrm{ab}}$ & $60.7^{\mathrm{ab}}$ & $58.5^{\mathrm{b}}$ & $59.8^{\mathrm{b}}$ & 1.68 & 0.026 & 0.027 \\
\hline NPN-CP/CP & $34.9^{\mathrm{b}}$ & $39.3^{\mathrm{ab}}$ & $39.2^{\mathrm{ab}}$ & $39.3^{\mathrm{ab}}$ & $41.5^{\mathrm{a}}$ & $40.2^{\mathrm{a}}$ & 1.68 & 0.026 & 0.027 \\
\hline $\mathrm{ADF}-\mathrm{CP} / \mathrm{CP}$ & $24.9^{\mathrm{abc}}$ & $24.0^{\mathrm{bc}}$ & $25.1^{\mathrm{abc}}$ & $26.3^{\mathrm{ab}}$ & $28.2^{\mathrm{a}}$ & $22.6^{\mathrm{c}}$ & 1.24 & 0.211 & 0.001 \\
\hline Ether extract & $3.1^{\mathrm{d}}$ & $3.3^{\mathrm{cd}}$ & $3.7^{\mathrm{ab}}$ & $3.6^{\mathrm{abc}}$ & $3.5^{\mathrm{bc}}$ & $3.8^{\mathrm{a}}$ & 0.10 & 0.001 & 0.339 \\
\hline Crude ash & $11.7^{\mathrm{b}}$ & $12.7^{\mathrm{a}}$ & $12.3^{\mathrm{ab}}$ & $12.7^{\mathrm{a}}$ & $12.2^{\mathrm{ab}}$ & $12.4^{\mathrm{ab}}$ & 0.28 & 0.680 & 0.577 \\
\hline $\mathrm{NDF}$ & 53.8 & 52.3 & 52.5 & 52.4 & 52.4 & 51.2 & 0.91 & 0.032 & 0.978 \\
\hline $\mathrm{ADF}$ & $41.1^{\mathrm{c}}$ & $42.4^{\mathrm{abc}}$ & $43.5^{\mathrm{a}}$ & $43.2^{\mathrm{ab}}$ & $41.1^{\mathrm{c}}$ & $41.9^{\mathrm{bc}}$ & 0.51 & 0.095 & 0.955 \\
\hline NFC & 18.7 & 18.5 & 18.0 & 18.0 & 18.7 & 19.3 & 0.92 & 0.216 & 0.498 \\
\hline
\end{tabular}

${ }^{1}$ The mean of 10 observations.

${ }^{2} \mathrm{TP}=$ True protein, NPN = Non-protein nitrogen, NDF = Neutral detergent fiber, ADF $=$ Acid detergent fiber, NFC $=$ Non-fibrous carbohydrate.

${ }_{a, b, c, d}$ Means with different superscripts within the same row are significantly different $(\mathrm{p}<0.05)$.

model used was as follows:

$$
\mathrm{Y}_{i j k}=\mu+\mathrm{F}_{i}+\mathrm{C}_{j}+\mathrm{e}_{i j k}
$$

Where $\mathrm{Y}_{i j k}$ is the dependent variable, $\mu$ is the overall mean, $\mathrm{F}_{i}$ is the fixed effect of the feed ( $i=1$ to 3 ), $\mathrm{C}_{j}$ is the random and block effect of the cow ( $j=1$ to 2$)$, and $\mathrm{e}_{i j k}$ is the error term. A value of $\mathrm{p}<0.05$ was considered to be significant.

\section{RESULTS}

\section{Ensiling characteristics of BF-based silage}

Chemical, fermentative, and microbial parameters: The changes in chemical composition of BF-based silage are presented in Table 2 . The ensiling period ( 0 to $28 \mathrm{~d}$ ) affected $(p<0.01)$ the chemical composition and the DM, $\mathrm{OM}, \mathrm{CP}, \mathrm{NPN}-\mathrm{CP} / \mathrm{CP}, \mathrm{ADF}-\mathrm{CP} / \mathrm{CP}$, EE, crude ash, and $\mathrm{ADF}$ content in the BF-based silage. Compared with the observation before ensiling, ensiling for up to $28 \mathrm{~d}$ decreased the DM content but increased NPN-CP/CP and ADF-CP/CP content quadratically $(\mathrm{p}<0.05)$. Specifically, the DM and the OM content was reduced by $1.5 \%$ and $0.7 \%$, respectively, while the $\mathrm{CP}$ content was increased by $0.6 \%$; EE, by $0.7 \%$; crude ash, by $0.7 \%$; and $\mathrm{ADF}$, by $0.8 \%$. Generally, the ensilation-induced change in the chemical composition of the BF-based silage was very low.

The length of ensiling period ( 0 to $28 \mathrm{~d}$ ) affected all the measured fermentative and microbial parameters of BFbased silage $(\mathrm{p}<0.01)$, as shown in Table 3. Ensiling for up

Table 3. The effects of the ensilation period of by-product feed-based silage on fermentation parameters and microbes ${ }^{1}$

\begin{tabular}{|c|c|c|c|c|c|c|c|c|c|}
\hline \multirow[t]{2}{*}{ Item } & \multicolumn{6}{|c|}{ Ensilation period } & \multirow[t]{2}{*}{ SE } & \multicolumn{2}{|c|}{$\begin{array}{c}\text { Polynomial } \\
\text { contrast degree }\end{array}$} \\
\hline & $0 \mathrm{~d}$ & $3 \mathrm{~d}$ & $5 \mathrm{~d}$ & $7 \mathrm{~d}$ & $14 \mathrm{~d}$ & $28 \mathrm{~d}$ & & Linear & Quadratic \\
\hline & -- & & & $-\%$ & & $x_{-}$ & & & \\
\hline \multicolumn{10}{|l|}{ Fermentation } \\
\hline $\mathrm{pH}$ & $5.11^{\mathrm{ab}}$ & $5.19^{\mathrm{ab}}$ & $5.19^{\mathrm{ab}}$ & $5.22^{\mathrm{a}}$ & $5.13^{\mathrm{ab}}$ & $5.10^{\mathrm{b}}$ & 0.040 & 0.049 & 0.042 \\
\hline Acetic acid (mM/g) & $206.8^{\text {bcd }}$ & $226.9^{\mathrm{bc}}$ & $45.0^{\mathrm{d}}$ & $127.9^{\mathrm{cd}}$ & $309.3^{\mathrm{ab}}$ & $449.6^{\mathrm{a}}$ & 58.38 & 0.001 & 0.046 \\
\hline Butyric acid $(\mathrm{mM} / \mathrm{g})$ & $2.3^{\mathrm{a}}$ & $1.6^{\mathrm{a}}$ & $\mathrm{ND}^{2}$ & ND & $1.0^{\mathrm{b}}$ & $1.1^{\mathrm{ab}}$ & 0.42 & 0.101 & 0.001 \\
\hline Lactic acid (\%) & $0.28^{\mathrm{b}}$ & $1.98^{\mathrm{a}}$ & $1.99^{\mathrm{a}}$ & $1.97^{\mathrm{a}}$ & $2.03^{\mathrm{a}}$ & $2.02^{\mathrm{a}}$ & 0.028 & 0.001 & 0.001 \\
\hline Water-soluble carbohydrate $(\%)$ & $1.76^{\mathrm{a}}$ & $1.02^{\mathrm{b}}$ & $1.06^{\mathrm{b}}$ & $1.04^{\mathrm{b}}$ & $0.96^{\mathrm{b}}$ & $0.97^{\mathrm{b}}$ & 0.038 & 0.001 & 0.001 \\
\hline $\mathrm{NH}_{3}-\mathrm{N}(\mathrm{ppm})$ & $169.5^{\mathrm{a}}$ & $193.2^{\mathrm{b}}$ & $194.0^{\mathrm{b}}$ & $201.8^{\mathrm{b}}$ & $204.3^{\mathrm{b}}$ & $227.9^{c}$ & 5.60 & 0.001 & 0.028 \\
\hline \multicolumn{10}{|l|}{ Microbes } \\
\hline Total bacteria $\left(\log _{10} \mathrm{cfu} / \mathrm{g}\right)$ & $9.22^{\mathrm{a}}$ & $9.16^{\mathrm{ab}}$ & $9.10^{\mathrm{ab}}$ & $9.03^{\mathrm{b}}$ & $8.76^{\mathrm{c}}$ & $8.85^{\mathrm{c}}$ & 0.056 & 0.001 & 0.001 \\
\hline Lactic acid bacteria $\left(\log _{10} \mathrm{cfu} / \mathrm{g}\right)$ & $9.25^{\mathrm{a}}$ & $9.18^{\mathrm{a}}$ & $9.17^{\mathrm{a}}$ & $8.99^{\mathrm{b}}$ & $8.93^{\mathrm{b}}$ & $8.88^{\mathrm{b}}$ & 0.058 & 0.001 & 0.002 \\
\hline
\end{tabular}

${ }^{1}$ Means of 10 observations. ${ }^{2}$ ND $=$ Not detected.

${ }^{a, b, c, d}$ Means with different superscripts within the same row are significantly different $(\mathrm{p}<0.05)$. 
to $28 \mathrm{~d}$ produced only small alterations in $\mathrm{pH}$ while producing quadratic decreases in the butyric acid and WSC content $(\mathrm{p}<0.05)$ and increases in the acetic acid, lactic acid, and $\mathrm{NH}_{3}-\mathrm{N}$ content $(\mathrm{p}<0.05)$. The lactic acid content increased about 7-fold after ensiling $(p<0.0001)$. The butyric acid levels remained very low (below $2 \mathrm{mM} / \mathrm{g}$ ) during the entire ensiling period. This implies that the silage was not aerobically deteriorated.

Counts of total bacteria and LAB in the BF-based silage decreased quadratically with prolonged ensiling ( $\mathrm{p}<0.005)$. The bacterial count $(\mathrm{p}<0.05)$ decreased from the second week of ensiling, as did the LAB counts from the first week of ensiling $(p<0.05)$. Thereafter, counts of total bacteria and LAB remained unchanged (about $10^{8} \mathrm{cfu} / \mathrm{g}$ ) until day 28 of ensilation.

The chemical composition, in situ fractionation, and ruminal disappearance rate

The BF-based silage used in the in situ bag test was that from the 14-d ensiling period (Table 2) and its chemical composition, in situ fractionation, and ruminal disappearance rate were compared with that of rice straw and ryegrass straw. The rice straw used in this test contained 73.9\% DM, 3.6\% CP (84.1\% TP/CP), 1.1\% EE, 9.3\% crude ash, $72.8 \% \mathrm{NDF}, 47.1 \% \mathrm{ADF}$, and $13.3 \% \mathrm{NFC}$, while the ryegrass straw contained $90.8 \%$ DM, 5.4\% $\mathrm{CP}(67 \%$ TP/CP), $0.5 \%$ EE, $3.5 \%$ crude ash, $80.3 \%$ NDF, $65.2 \%$ ADF, and $10.2 \%$ NFC on a DM basis (data not shown).

The DM, NDF, and CP fractions of the feedstuffs tested in the in situ bag test are shown in Table 4. The watersoluble and filterable DM fraction was increased in the BFbased silage, while the insoluble degradable DM fraction in this silage was lower than that in rice or ryegrass straw $(\mathrm{p}<0.05)$. The non-degradable DM fraction of this silage was lower than that of rice straw $(\mathrm{p}<0.05)$, while digestible and indigestible NDF fractions were lower and higher, respectively, compared to that of rice or ryegrass straw $(\mathrm{p}<$ 0.05). This silage had higher water-soluble and filterable, and lower insoluble degradable and lower non-degradable $\mathrm{CP}$ fractions compared to that in the rice straw or ryegrass straw $(\mathrm{p}<0.05)$.

The DM disappearance rate from the silage in the early stage of ruminal incubation was higher than that of rice straw and ryegrass straw $(\mathrm{p}<0.05)$; however, as the ruminal incubation progressed, the difference between the silage and rice straw decreased gradually (data not shown). The NDF disappearance rate from the silage after $72 \mathrm{~h}$ of incubation was $15 \%$ and $18 \%$ lower than that of rice straw or ryegrass straw $(\mathrm{p}<0.05)$, respectively. The $\mathrm{CP}$ disappearance rate from the silage following $24 \mathrm{~h}$ of ruminal incubation was $95.9 \%$ that of the total $\mathrm{CP}$ disappearance. The CP disappearance rate from the silage was consistently much higher throughout the incubation period, and at $48 \mathrm{~h}$ of incubation, it was $39 \%$ and $24 \%$ higher than that of rice straw and ryegrass straw $(\mathrm{p}<0.05)$, respectively.

\section{The in situ degradability of nutrients}

The estimated DM, CP, and NDF degradabilities at two rates of passage $\left(K_{\mathrm{p}} \mathrm{B} 0.025\right.$ and 0.05$)$ are shown in Table 5. In general, the rate of $\mathrm{DM}$ and $\mathrm{CP}$ degradation was higher in the BF-based siliage, while that of NDF was lower, at both passage rates $(\mathrm{p}<0.05)$, when compared to that in rice straw and ryegrass straw. At the passage rate $\left(K_{\mathrm{p}} \mathrm{B}=0.05\right)$ of animal production level, the DM degradability in the silage was about 1.8-fold and 1.6-fold higher than that in rice straw and ryegrass straw $(\mathrm{p}<0.05)$. Additionally, compared to the rice or ryegrass straw values, NDF degradability in the BF-based silage was $28 \%$ and $32 \%$ lower, while the CP degradability was 2.3-fold and 2.1-fold higher, respectively $(\mathrm{p}<0.05)$.

\section{DISCUSSION}

\section{The ensiling characteristics of BF-based silage}

Chemical, fermentative, and microbial parameters: The level of ensilation-induced change in the chemical

Table 4. In situ fraction of the DM, NDF and CP content of different feedstuffs ${ }^{1}$

\begin{tabular}{|c|c|c|c|c|c|}
\hline Item & Rice straw & Ryegrass straw & BF-based silage $^{2}$ & $\mathrm{SE}$ & $\mathrm{p}$ value \\
\hline Dry matter fraction & ------ & - $\%$ & 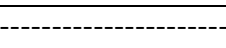 & & \\
\hline Water-soluble and $45-\mu \mathrm{m}$ filterable & $17.4^{\mathrm{b}}$ & $18.6^{\mathrm{b}}$ & $44.5^{\mathrm{a}}$ & 1.05 & $<0.0001$ \\
\hline Insoluble degradable & $37.2^{\mathrm{b}}$ & $44.2^{\mathrm{a}}$ & $20.2^{\mathrm{c}}$ & 1.75 & $<0.0001$ \\
\hline Non-degradable & $45.4^{\mathrm{a}}$ & $37.2^{\mathrm{b}}$ & $35.3^{\mathrm{b}}$ & 1.15 & $<0.0001$ \\
\hline \multicolumn{6}{|l|}{ NDF fraction } \\
\hline Digestible & $53.5^{\mathrm{a}}$ & $56.6^{\mathrm{a}}$ & $38.7^{\mathrm{b}}$ & 2.11 & $<0.0001$ \\
\hline Indigestible & $46.5^{\mathrm{b}}$ & $43.4^{\mathrm{b}}$ & $61.3^{\mathrm{a}}$ & 2.11 & $<0.0001$ \\
\hline \multicolumn{6}{|l|}{$\mathrm{CP}$ fraction } \\
\hline Water-soluble and $45-\mu \mathrm{m}$ filterable & $28.8^{\mathrm{b}}$ & $27.7^{\mathrm{b}}$ & $73.0^{\mathrm{a}}$ & 2.01 & $<0.0001$ \\
\hline Insoluble degradable & $18.1^{\mathrm{b}}$ & $33.0^{\mathrm{a}}$ & $8.2^{\mathrm{c}}$ & 2.69 & $<0.0001$ \\
\hline Non-degradable & $53.1^{\mathrm{a}}$ & $39.4^{\mathrm{b}}$ & $18.8^{\mathrm{c}}$ & 2.86 & $<0.0001$ \\
\hline
\end{tabular}

\footnotetext{
${ }^{1}$ Means of 4 observations. ${ }^{2}$ By-product feed-based silage.
}

${ }^{a, b, c}$ Means with different superscripts within the same row are significantly different $(\mathrm{p}<0.05)$. 
Table 5. The in situ dry matter (DM), crude protein (CP) and neutral detergent fiber (NDF) degradabilities at 2 rates of passage $e^{1,2}$

\begin{tabular}{|c|c|c|c|c|c|}
\hline Item & Rice straw & Ryegrass straw & BF-based silage $^{3}$ & SE & $\mathrm{p}$ value \\
\hline \multicolumn{6}{|c|}{ DM degradability at $K_{\mathrm{p}} \mathrm{B}$} \\
\hline 0.025 & $31.7^{\mathrm{c}}$ & $35.9^{\mathrm{b}}$ & $47.8^{\mathrm{a}}$ & 0.60 & $<0.0001$ \\
\hline 0.05 & $26.2^{\mathrm{c}}$ & $29.4^{\mathrm{b}}$ & $46.3^{\mathrm{a}}$ & 0.59 & $<0.0001$ \\
\hline \multicolumn{6}{|c|}{ NDF degradability at $K_{\mathrm{p}} \mathrm{B}$} \\
\hline 0.025 & $37.6^{\mathrm{a}}$ & $39.7^{\mathrm{a}}$ & $27.0^{\mathrm{b}}$ & 1.46 & $<0.0001$ \\
\hline 0.05 & $29.0^{\mathrm{a}}$ & $30.6^{\mathrm{a}}$ & $20.8^{\mathrm{b}}$ & 1.11 & $<0.0001$ \\
\hline \multicolumn{6}{|c|}{$\mathrm{CP}$ degradability at $K_{\mathrm{p}} \mathrm{B}$} \\
\hline 0.025 & $33.2^{\mathrm{c}}$ & $40.1^{\mathrm{b}}$ & $73.8^{\mathrm{a}}$ & 2.03 & $<0.0001$ \\
\hline 0.05 & $31.3^{\mathrm{b}}$ & $35.3^{\mathrm{b}}$ & $73.4^{\mathrm{a}}$ & 1.95 & $<0.0001$ \\
\hline
\end{tabular}

${ }^{1}$ The mean of 4 observations. ${ }^{2}$ The rate of passage $\left(K_{\mathrm{p}} \mathrm{B}\right)$ was assumed to be 0.025 and $0.05 / \mathrm{h} .{ }^{3}$ By-product feed-based silage.

${ }^{a, b, c}$ Means with different superscripts within the same row are significantly different $(p<0.05)$.

composition of the BF-based silage was very low, as reported in other studies using SMS silage (Kim et al., 2008b; Kwak et al., 2009). Since mixing and packing of the mixture when ensiling become difficult with the blending of a large quantity of straw, a minimal amount of straw was used to provide a normal level of physically effective NDF. The peNDF $1.18(37.8 \%)$ of BF-based silage in the present study was a little higher than the value $(35.1 \%)$ reported by Lee et al. (2010a). About $20 \%$ of eNDF in dry diet is required to maintain the rumen $\mathrm{pH}$ at more than 6.2 , and $25 \%$ eNDF is required to maintain the $\mathrm{pH}$ necessary for maximum forage digestion and microbial growth (NRC, 2000).

The ensilation of SMS with microbial inoculants and molasses could reduce $\mathrm{pH}$ and WSC and increase the lactic acid content compared with that prior to ensilation (Kim et al., 2008b; Kwak et al., 2009). The increase in the lactic acid content in the present study is attributed to the conversion of WSC into lactic acid by LAB, as suggested by Wang et al. (2003). The decrease in the WSC level indicated that the rate of WSC conversion into microbial biomass or other metabolites exceeded that of carbohydrate breakdown into WSC. Generally, the anaerobic fermentation of SMS reduced the $\mathrm{pH}$ of the silage (Kwak et al., 2009). However, in the present study, the silage $\mathrm{pH}$ was not reduced, probably due to the added RPB, which would produce alkaline ammonia. A pH of 4 to 5 is desired when using fermented feed ingredients, because below $\mathrm{pH} 4$, voluntary feed intake is decreased and over $\mathrm{pH} 5$, microbial spoilage is likely to occur (Lee et al., 2004). The $\mathrm{pH}$ of the ensiled RPB alone usually remained above 4.5 due to the buffering capacity of ammonia in RPB, and a pH above 5.5 still effectively destroyed coliforms (Duque et al., 1978). In the present study, although the silage $\mathrm{pH}$ was slightly more than 5, the silage showed an appropriate appearance and fermentative odor without any fungal occurrence.

The counts of total bacteria and LAB started to reduce from $10^{9}$ to $10^{8} \mathrm{cfu} / \mathrm{g}$ level between the first and second week of ensilation in the present study. These trends were also observed in the study of Kim et al. (2008b), when sawdust-based SMS inoculated with mixed microbes was ensiled for 8 weeks.

\section{In situ fractionation and the ruminal disappearance rate}

The high water-soluble and filterable DM fraction of the BF-based silage was attributed to high $\mathrm{CP}$ and NFC components of RPB and rice bran, as shown in Table 1. Thus, the non-degradable DM fraction of the BF-based silage was $10 \%$ lower than that of rice straw.

In the present study, the digestible NDF fraction of the BF-based silage was lower than that of the straws. Makela et al. (2002) reported that, during mushroom cultivation, lignocellulose in SMS was decomposed by the mycelium, which preferentially utilizes digestible cellulose and hemicellulose. Fazaeli and Masoodi (2006) reported that the lignin content of SMS was increased during mushroom cultivation. Bonnen et al. (1994), and Ball and Jackson (1995) reported that the lignin content negatively correlated with digestibility. These phenomena must be related with the low digestible NDF fraction of the BF-based silage.

The water-soluble and filterable $\mathrm{CP}$ fraction in the $\mathrm{BF}$ based silage was higher than that of rice straw and ryegrass straw; this was attributed to the high NPN-CP/CP content in SMS (41.5\%, Table 2) and RPB (46.1\%, Table 1). The relatively low digestible NDF fraction of the silage was attributed to the relatively less digestible sawdust fiber, which is the main fibrous component in SMS. The NDF fraction and its ruminal disappearance rate in rice straw in the present study were similar (within 1 to $2 \%$ points) to the values reported by Kim et al. (2011). Compared with that of raw rice straw, the rate of disappearance of DM and $\mathrm{CP}$ from spent rice straw (SMS of Agaricus bisporus) was higher, while that of NDF was lower (Kim et al., 2011), similar to the results of the present study.

\section{The in situ degradability of nutrients}

The estimated degradabilities of DM, NDF, and CP in 
the rice straw in the present study were similar to the values $(28.7,30.5$, and $34.1 \%$, respectively) reported by Kim et al. (2011). In the present study, the rate of DM or CP degradation in the BF-based silage was higher than that of rice straw and ryegrass straw. Kim et al. (2010) also reported that NDF digestibility was decreased by $4.8 \%$ when they replaced $50 \%$ of the rice straw in a sheep diet with ensiled SMS. The major fiber source in the SMS and RPB used in the present study were sawdust and rice hull respectively, both of which generally had a low amount of digestible fiber (Kim et al., 2007c; NIAS, 2012). For sawdust-based SMS-derived DM and NDF, the rate of ruminal disappearance or degradability was lower than that of corncobs- or cotton waste-based SMS (Bae et al., 2006). These results indicate that the relatively low NDF degradability of the BF-based silage could be attributable to the sawdust content, as this material contains a high level of indigestible fiber. The relatively high degradabilities of DM and CP and the low degradability of NDF in the BF-based silage were attributed to the high water-soluble and filterable fractions of DM and CP and the low digestible fraction of NDF, respectively.

\section{CONCLUSION}

The examination of chemical, fermentative, and microbial parameters indicated that the BF-based silage was fermented and could be stored well up to the fourth week of ensilation. The estimated rate of degradation of the BFbased silage DM and $\mathrm{CP}$ were much higher than that of rice straw and ryegrass straw, and vice versa for NDF. The BFbased silage, which showed high $\mathrm{CP}$ solubility and low NDF degradability, may be more suitable when used in combination with conventional roughage, which contains low-quality proteins and shows high NDF degradability. Thus, BF-based silage can be used in combination with conventional roughage to improve forage quality. The low ruminal NDF digestion of the BF-based silage would be increased when the sawdust-based SMS is substituted with corncobs-based SMS. These results show that it may be possible to manufacture cheap good quality BF-based roughage for use in Asian countries facing a roughage scarcity by ensiling SMS, RPB, rice bran, and a minimal amount of straw.

\section{ACKNOWLEDGEMENTS}

This study was carried out with the support of the "Cooperative Research Program for Agriculture Science and Technology Development (Project No. PJ00938201)" Rural Development Administration, Republic of Korea.

\section{REFERENCES}

AOAC. 2000. Official methods of analysis, 17th Ed. Association of Official Analytical Chemists, Washington, DC, USA.

Armentano, L. E., T. A. Herrinton, C. E. Polan, A. J. Moe, J. H. Herbein, and P. Umstadt. 1986. Ruminal degradation of dried brewers grains, wet brewers grains and soybean meal. J. Dairy Sci. 69:2124-2133.

Bae, J. S., Y. I. Kim, S. H. Jung, Y. G. Oh, and W. S. Kwak. 2006. Evaluation on feed-nutritional value of spent mushroom (Pleurotus osteratus, Pleurotus eryngii, Flammulina velutupes) substrates as a roughage source for ruminants. Korean J. Anim. Sci. Technol. 48:237-246.

Ball, A. S. and A. M. Jackson. 1995. The recovery of lignocellulose degrading enzymes from spent mushroom compost. Bioresour. Technol. 54:311-314.

Barker, S. B. and W. H. Summerson. 1941. The colorimetric determination of lactic acid in biological material. J. Biol. Chem. 138:535-554.

Bonnen, A. M., L. H. Anton, and A. B. Orth. 1994. Lignin degrading enzymes of the commercial button mushroom, Agaricus bisporus. Appl. Environ. Microbiol. 60:960-965.

Chaney, A. L. and E. P. Marbach. 1962. Modified reagents for the determination of urea and ammonia. Clim. Chem. 8:130-132.

Cho, W. M., B. H. Paek, S. W. Kang, J. S. Kim, and Y. K. Kim. 2001. Effects of dietary supplements of clay minerals on the growth performance and immunity in growing Hanwoo steers. Korean J. Anim. Sci. Technol. 43:203-210.

Dubois, M., K. A. Gilles, J. K. Hamilton, P. A. Rebers, and F. Smith. 1956. Colorimetric method for determination of sugars and related substances. Anal. Chem. 28:350-356.

Duque, J. A., J. P. Fontenot, K. E. Webb, Jr. and J. C. A. Berger. 1978. Fermentation and digestibility of broiler litter ensiled at different moisture levels by addition of whey or water. Virginia Polytechnic Institute and State University Res. Div. Rep. 174:108.

Erwin, E. S., G. J. Naro, and E. M. Emery. 1961. Volatile fatty acid analysis of blood and rumen fluid by gas chromatography. J. Dairy Sci. 44:1768-1771.

Fazaeli, H. and A. R. Talebian Masoodi. 2006. Spent wheat straw compost of Agaricus bisporus mushroom as ruminant feed. Asian-Aust. J. Anim. Sci. 19:845-851.

Fontenot, J. P. 2001. Utilization of poultry litter as feed for beef cattle. FDA Public Hearing on Animal Feeding Regulation, Kansas City, MO, USA.

Gao, L., H. Yang, X. Wang, Z. Huang, M. Ishii, Y. Igarashi, and Z. Cui. 2008. Rice straw fermentation using lactic acid bacteria. Bioresour. Technol. 99:2742-2748.

Goering, H. R. and P. J. Van Soest. 1970. Forage fiber analysis. Handbook 379. US Department of Agriculture, USA.

Kang, S. W., J. S. Kim, W. M. Cho, B. S. Ahn, K. S. Ki, and Y. S. Son. 2002. Effect of domestic clay minerals on growth performance and carcass characteristics in growing-fattening Hanwoo steers. Korean J. Anim. Sci. Technol. 44:327-340.

Kim, Y. I., W. M. Cho, S. K. Hong, Y. K. Oh, and W. S. Kwak. 2011. Yield, nutrient characteristics, ruminal solubility and degradability of spent mushroom (Agaricus bisporus) substrates for ruminants. Asian-Aust. J. Anim. Sci. 24:15601568 . 
Kim, Y. I., S H. Jeong, J. S. Seok, S. Y. Yang, J. W. Huh, and W. S. Kwak. 2008a. Isolation and identification of hydrolytic enzyme-producing bacteria from spent mushroom substrate. Korean J. Anim. Sci. Technol. 50:713-720.

Kim, Y. I., S. H. Jung, J. S. Seok, S. Y. Yang, J. W. Huh, and W. S. Kwak. 2007b. Isolation and identification of high cellulolytic bacteria from spent mushroom substrate and determination of optimal medium conditions for the growth. Kor. J. Microbiol. Biotechnol. 35:255-260.

Kim, Y. I., S. H. Jung, S. Y. Yang, J. W. Huh, and W. S. Kwak. 2007c. Effects of cellulolytic microbes inoculation during deep stacking of spent mushroom substrates on cellulolytic enzyme activity and nutrients utilization by sheep. Korean J. Anim. Sci. Technol. 49:667-676.

Kim, Y. I., J. S. Seok, and W. S. Kwak. 2008b. Effect of mixed microbes addition on chemical change and silage storage of spent mushroom substrates. Korean J. Anim. Sci. Technol. 50:831-838.

Kim, Y. I., J. S. Seok, and W. S. Kwak. 2010. Evaluation of microbially ensiled spent mushroom (Pleurotus osteratus) substrates (bed-type cultivation) as a roughage for ruminants. Korean J. Anim. Sci. Technol. 52:117-124.

Kwak, W. S., S. H. Jung, and Y. I. Kim. 2008. Broiler litter supplementation improves storage and feed-nutritional value of sawdust-based spent mushroom substrate. Bioresour. Technol. 99:2947-2955.

Kwak, W. S., Y. I. Kim, J. S. Seok, Y. K. Oh, and S. M. Lee. 2009. Molasses and microbial inoculants improve fermentability and silage quality of cotton waste-based spent mushroom substrate. Bioresour. Technol. 100:1471-1473.

Lee, K. S., K. Y. Lee, C. S. Oh, D. G. Lee, and Y. J. Kim. 2004. Effect of aeration for the probiotic feed production from food wastes by Lactobacillus acidophilus and Saccharomyces cerevisiae. J. KOWREC. 11:114-119.

Lee, S. M., Y. I. Kim, and W. S. Kwak. 2010a. Effect of byproduct mixing silage feeding on the eating and ruminating behavior of Hanwoo steer. J. Korean Grassl. Forage Sci. 30:159-168

Lee, S. M., Y. I. Kim, and W. S. Kwak. 2010b. Effects of dietary addition of bentonite on manure gas emission, health, production, and meat characteristics of Hanwoo (Bos Taurus coreanae) steers. Asian-Aust. J. Anim. Sci. 23:1594-1600.

Makela, M., S. Galkin, A. Hatakka, and T. Lundell. 2002. Production of organic acids and oxalate decarboxylase in lignin-degrading white rot fungi. Enzyme Microb. Technol. 30:542-549.
McCaskey, T. A., S. N. Britt, B. G. Ruffin, and J. T. Eason. 1994. Feed value of broiler litter for stocker cattle. Highlights of Alabama Agric. Res. 41:12.

Miller, E. L. 1982. Methods of assessing proteins for ruminants, including laboratory methods. In Protein Contribution of Feedstuffs for Ruminants: Application to Feed Formulation (Ed. E. L. Miller and I. H. Pike). Butterworth Scientific, London, pp. 18-35.

National Institute of Animal Science. 2012. Standard tables of feed composition in Korea. National Institute of Animal Science, RDA, Korea.

National Research Council. 2000. Nutrient requirements of beef cattle. Update of Seventh Revised Edition, 1996. National Academy Press, Washington, DC, USA.

National Research Council. 2001. Nutrient requirements of dairy cattle, 7th Rev. Ed., National Academy Press, Washington, DC, USA.

Nocek, J. E. 1985. Evaluation of specific variables affecting in situ estimates of ruminal dry matter and protein digestion. J. Anim. Sci. 60:1347-1358.

Ørskov, E. R., F. D. Hovell, and F. Mould. 1980. The use of the nylon bag technique for the evaluation of feedstuffs. Trop. Anim. Prod. 5:195-213.

Ørskov, E. R., M. Hughes-Jones, and M. E. Eliman. 1983. Studies on degradation and outflow rate of protein supplements in the rumen of sheep and cattle. Livest. Prod. Sci. 10:17-24.

Schneider, R. M., J. H. Harrison, and K. A. Loney. 1995. The effects of bacterial inoculants, beet pulp, and propionic acid on ensiled wet brewers grains. J. Dairy Sci. 78:1096-1105.

Smith, L. W., H. K. Goering, D. R. Waldo, and C. H. Gordon. 1971. In vitro digestion rate of forage cell wall components. J. Dairy Sci. 54:71-76.

Statistix7. 2000. User's manual. Analytical Software, Tallagassee, FL, USA

Van Soest, P. J., J. B. Robertson, and B. A. Lewis. 1991. Methods of dietary fiber, neutral detergent fiber, nonstarch polysaccharides in relation to animal nutrition. J. Dairy Sci. 74:3583-3597.

Wang, Q., J. Narita, N. Ren, T. Fukushima, Y. Ohsumi, K. Kusano, Y. Shirai, and H. I. Ogawa. 2003. Effect of pH adjustment on preservation of kitchen waste used for producing lactic acid. Water Air Soil Pollut. 144:405-418.

Weinberg, Z. G., Y. Chen, and P. Weinberg. 2008. Ensiling olive cake with and without molasses for ruminant feeding. Bioresour. Technol. 99:1526-1529. 